UDK 338.48(560)

DOI: 10.31651/2076-5843-2019-1-158-167

\author{
Hlushkova Tetiana Serhiivna \\ docent, \\ International University of Economics and Humanities \\ Named After Akademician Stepan Demianchuk \\ ORCID ID https://orcid.org/0000-0002-3146-3038 \\ tts1987@ukr.net \\ Ushakova Oksana Anatoliivna, \\ the 1 st category specialist, lecturer, \\ Technical College of NUWEE \\ ORCID ID https://orcid.org/0000-0001-6161-7344 \\ ksenya.5000.ks@gmail.com
}

\title{
TOURIST ECONOMIC SAFETY MANAGEMENT SYSTEM: EXPERIENCE OF THE REPUBLIC OF TURKEY
}

Turkey has introduced effective security measures in response to the recession provoked by the unstable situation. States, in which tourism occupies a significant economic niche, should take care of security, because the losses from a decrease in the tourist flow significantly exceed investments in measures for preventing such situations. First of all, Turkey should respond to the emergence of instability in a flexible pricing policy, as well as carefully monitor security not only in the resort area, but also in the capital and non-tourist cities, because rumors about the occurrence of danger in this region adversely affect the tourist image of the country.

Keywords: tourism, GDP, safety of tourists, tourist economic safety management system.

Introduction. Multiple factors impact the tourists' choice of leisure destination. These are the planned type of tourism, the duration of the trip, as a consequence, the remoteness of the chosen country, the development of the tourism infrastructure and the like. However, all of these things become insignificant if there is a serious threat to people's security in the country or region. Tourists wish to feel safe during their rest, and any information about the terrorist attacks, natural disasters or other problems may turn a potential guest of a country from making a journey to an unstable region.

Terrorist attacks are measureless disaster not only for bereaved families, but also for the whole country. The state loses its citizens. There's a difficulty in interacting with the international community. The economy of the country is bound to be crippled. It becomes especially noticeable in the countries, where the share of tourism in the economy is major, because, as previously stated, potential tourists are very sensitive to security in the region.

Literature review. Both domestic (S. P. Fokin, A. P. Golod, M. M. Marinin, O. O. Beidyk) and foreign scholars (I. Kovari, K. Zimanyi, I. Mansfeld) have explored the subject of the impact of security in the region on the sustainable development of tourism sphere. These studies have revealed the essence of the concept of security in tourism and have traced the influence of this factor on the development of tourism sphere. However, the tourism industry is developing rapidly, so current and integrated studies of one of the most important problems, that is provision of security, are relevant today.

The purpose of the article is to analyse the impact of security strategy of the states, especially those with epicenters of instability, on the financial receipts from tourism; to study the impact of terrorist and other threats on the tourist flow; to carry out an analysis of the state response to escalation of security situation, aimed at smoothing negative consequences of these events for tourism sphere. The Republic of Turkey (Turkey) was chosen as target of research. 
Results and discussion. Undoubtedly, Turkey is perceived by the foreigners as a tourist country. The tourism sphere provides great employment opportunities, contributes to financial savings in state and local budgets, promotes the growth in the living standards. To determine the role of the tourism industry in Turkey for the country's economy, we used the secondary data presented in the magazine "Travel and Tourism: the economic effect of 2017 - Turkey" [8, p.3].

The direct contribution of Travel and Tourism to GDP in 2016 was $4.1 \%$ of GDP. This primarily reflects the economic activity generated by industries such as hotels, travel agents, airlines and other passenger transportation services (excluding commuter services). But it also includes, for example, the activities of the restaurant and the leisure industries, directly supported by tourists. The direct contribution of Travel and Tourism to GDP is expected to grow by $4.9 \%$ pa.

The total contribution of Travel and Tourism to GDP (including wider effects from investment, the supply chain and induced income impacts) was 265 billion TRY in 2016 (12.5\% of GDP). It is forecast to rise by $4.4 \%$ pa to 411.3 billion by 2027 (13.8\% of GDP).

Travel and Tourism generated 495,000 jobs directly in 2016 (1.8\% of total employment). This includes employment by hotels, travel agencies, airlines and other passenger transportation services (excluding commuter services). It also includes, for example, the activities of the restaurant and leisure industries, directly supported by tourists.

By 2027, Travel and Tourism will account for 797,000 jobs directly, an increase of $5.1 \%$ pa over the next ten years.

Money, spent by foreign visitors to a country, is a key component of the direct contribution of the travel sector. It is expected to attract 28.5 million international tourists arrivals.

By 2027 international tourist arrivals are forecast to total 69 million people, generating expenditure of 150.7 billion TRY. It is of great importance that Turkey has succesfully managed to make the export of services several times higher than the import. Many European countries would like their domestic tourists to rest and spend money in their country. Therefore, Turkey imports much more currency than it exports (fig. 1).

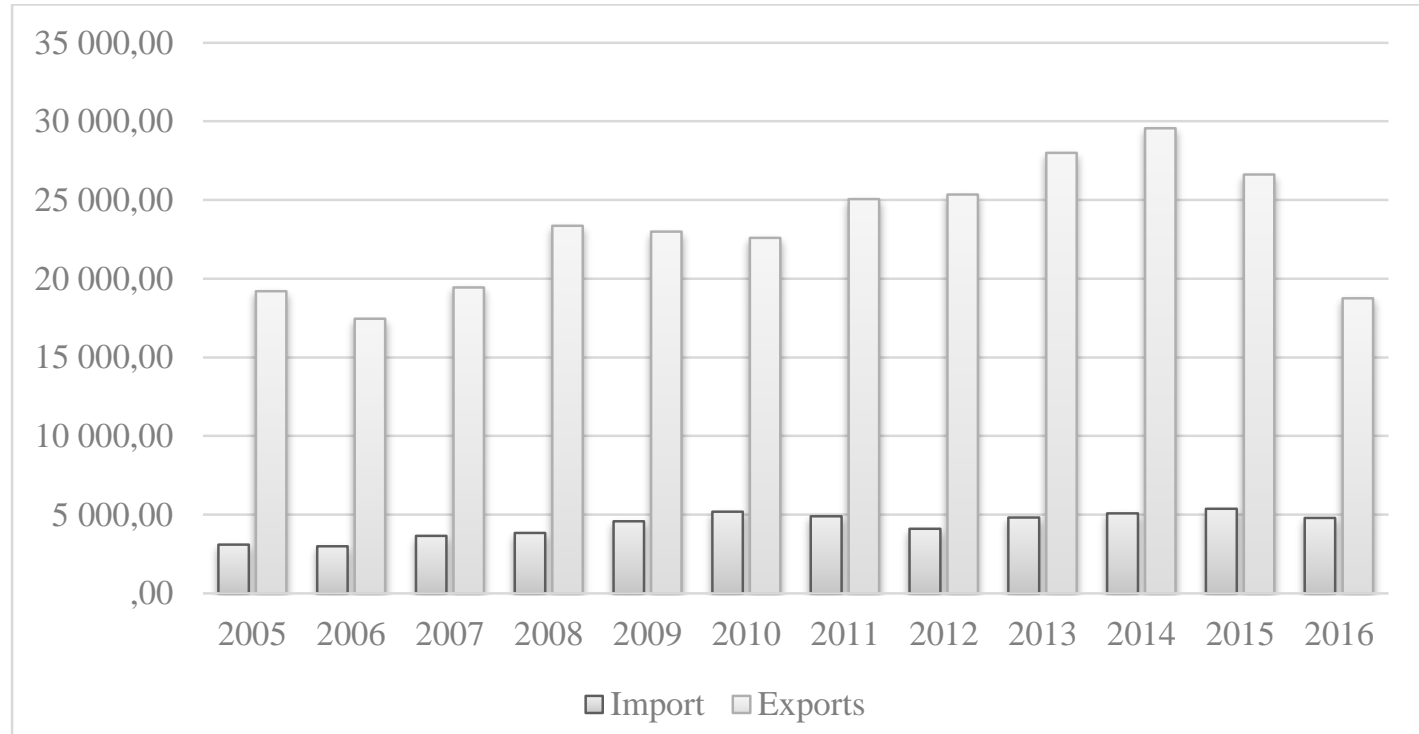

Fig. 1. Export and import of "Travel" service industry in the economy of Turkey, USD Million Created by the author based on the data obtained from the World Trade Organization)

Going along with the fact that the tourism industry constitutes a significant part of GDP and provides great employment opportunities, it requires significant investments for building tourism infrastructure.

Thus, tourism is one of the main industries of Turkey, and therefore it is important to ensure the stable development of this industry over the long term, which is difficult or impossible, depending on the situation, under the influence of factors that adversely affect the development of tourism. These factors include political instability, terrorist attacks and other phenomena that increase the uncertainty of tourists in a safe rest. 
Most of the risks here are associated with terrorist attacks. In its recent history, Turkey has already undergone terrorist attacks many times. In most cases, their organizers are the so-called "Islamic State" organization, which is supported by radical Islamist movements, as well as the Kurds, who have intensified in the struggle for independence. The coup d'état attempt, that happened on the night of July 15, 2016 further destabilized the situation in the country [1].

On the evening of June 28, 2016 three suicide bombers committed a terrorist attack in the Ataturk Airport in Istanbul. 36 people were killed, 147 were wounded [6].

On the evening of December 10, 2016 a bomb exploded after the football match outside Besiktas stadium in Istanbul. During the investigation, it turned out that it was a terrorist attack. The cause of the explosion was a car filled with explosives. Later, one more explosion occurred inside the stadium: the perpetrator of the attack used a "shahid belt". 44 people were killed, a large number of people were injured [6].

According to the World Tourism Organization, this situation immediately had an impact on tourist flows. Compared to the previous year, in 2016 the number of tourists who arrived in Turkey decreased (Fig. 2). The country dropped from the IV rank to the last position in the ranking of top 10 countries by tourist flows. This is due to the fact that the flow dynamics is $0,8 \%$. UNWTO cites the terrorist threat and political instability in 2016 as the reason of this negative trend [2, p.7].

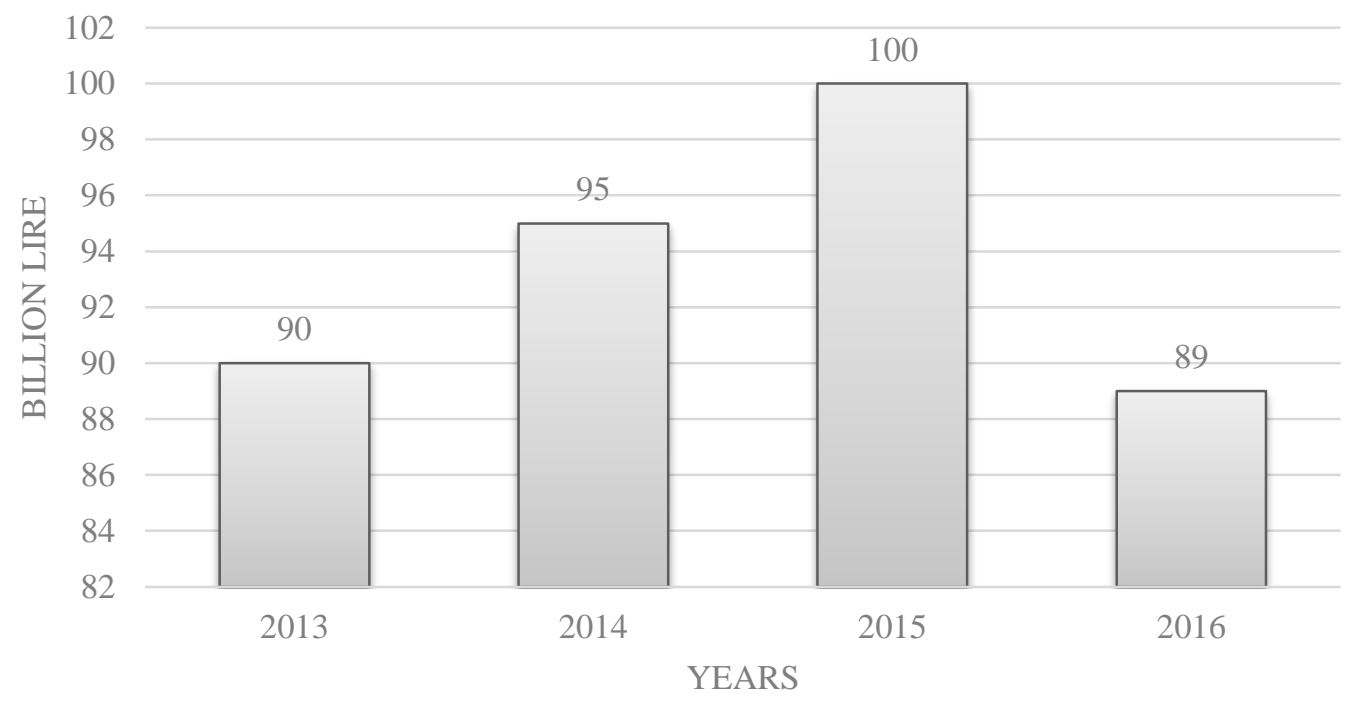

Fig. 2. Contribution of Travel and Tourism to GDP of Turkey Created according to UNWTO Toutism Highlights)

In the report of the World Economic Forum for 2017, the security index of Turkey as a tourist country is 4.05 , which provides the state with $116^{\text {th }}$ position in the rating for this indicator among 136 countries [1, p. 10]. Such a low number encourages the authorities to take more care to prevent terrorist attacks, because, to a greater extent, it is the terrorist threat that is the main source of danger to the tourists. As for crime, Turkey can boast a rather stable situation, and the tourists can feel the atmosphere of hospitality and security on the streets of Turkish cities.

According to the Ministry of Culture and Tourism of Turkey, the total flow of tourists into the country in 2016 decreased by $10.3 \%$ compared with the previous years. This means that approximately 9.2 million fewer foreign visitors arrived in the country, therefore, Turkey's tourism profits decreased by $\$ 10$ billion [4]. As a percentage, revenues to the Turkish economy from the tourism sector decreased by $16.5 \%$ in the first quarter of 2016 compared to the same period in 2015 . According to the Turkish Statistical Institute (TUIK), during the first three months of 2016, revenues from tourism became lower and amounted to $\$ 4.07$ billion.

The decline in Turkey's profits from tourism was a logical consequence of a sharp decrease in the number of tourists, who in March 2016 arrived by 13\% less than in the same month of 2015 
(Fig. 3). The Ministry of Tourism of Turkey calls this fall the most rapid since October 2006.

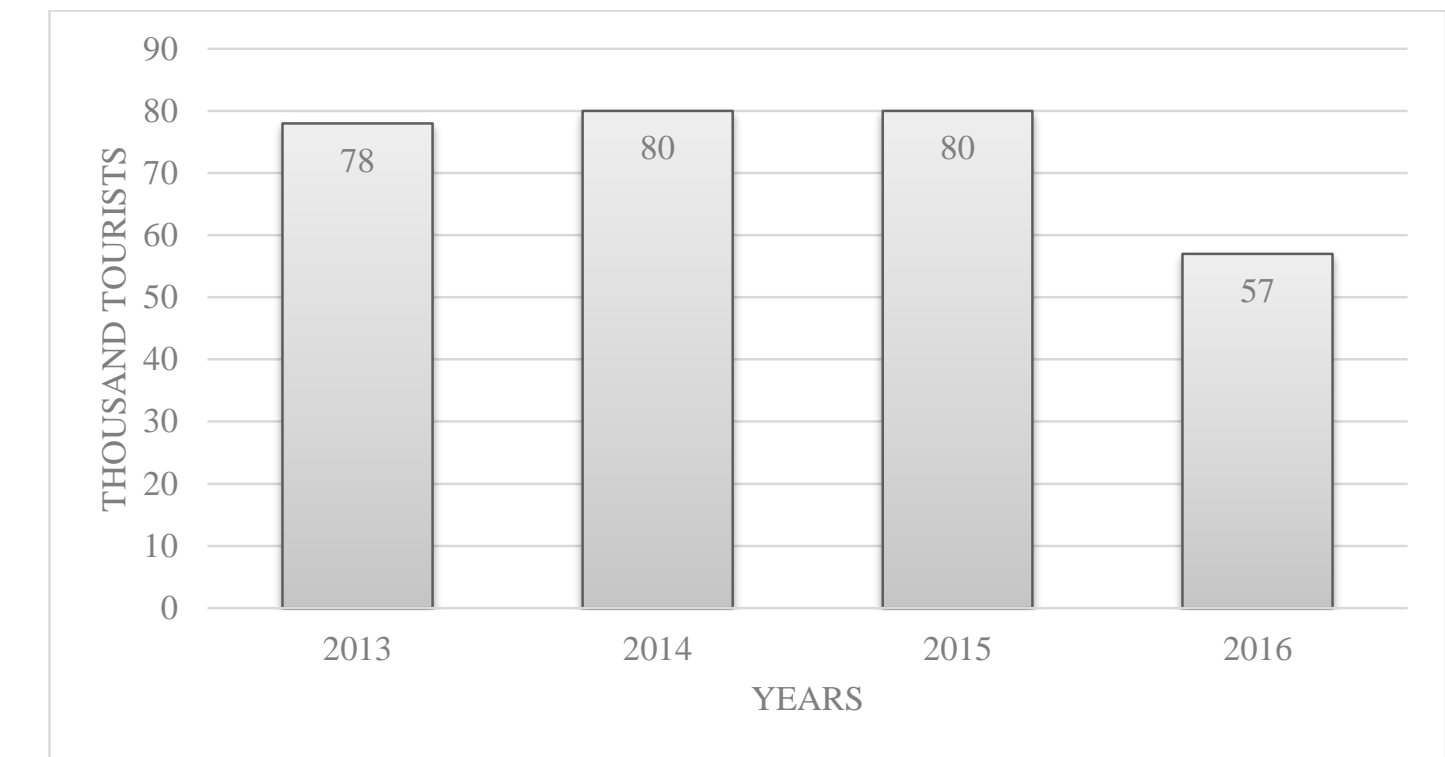

\section{Fig. 3. Arrival of international travellers to Turkey \\ Created according to UNWTO Toutism Highlights)}

The diplomatic conflict with the Russian Federation also had an impact on reducing the flow of tourists into the country, but the main argument of cancellation of travel by Europeans was the safety factor. In April 2016, after the terrorist attack, hotels received $40 \%$ of the refusals from the reserved rooms by German tourists [7].

Thus, 2016 has become very unfavorable for tourism in Turkey. Several terrorist attacks provoked a rapid decline in tourist flow into the country, and, as a result, revenues to the state budget from tourism as a branch decreased. This trend indicates a direct link between the security factor and the success of the tourism sector in the country and the profits from this sphere. However, Turkey was able to recover from these disasters. It set measures to enhance security, reduced prices for the rest, and thus quickly resumed the tourist flow, which proves the viability of the country's security system even in such difficult conditions. Therefore, we will consider the main components of the administrative policy in the field of ensuring the safety of tourists in more detail in each field of tourism, the elements of which constitute the tourist product.

The most comfortable way to get to Turkey is air transport, due to the fact that the state is separated from most of the countries "suppliers" of tourists by sea. In addition, the possibility of booking travel agencies charter flights allows to make holidays in Turkey affordable, and travel - comfortable.

The guests of Turkey are hosted by 8 modern international airports, among which Antalya International Airport, Ataturk International Airport in Istanbul, Dalaman International Airport and Milas-Bodrum International Airport are the most popular among Ukrainian tourists.

Tourists wishing to visit the Anatolian coast, arrive at Antalya International Airport, located $10 \mathrm{~km}$ east of the city center. The operator of the airport is the ICFAirports organization .

Most Muslim countries have a fairly high level of terrorist threat. Especially this danger is concentrated in areas of large crowds of people, which include airports. However, regarding the Antalya International Airport, it is worth noting a thorough approach to security control. First of all, as in other airports in the world, the baggage and carry-on baggage of passengers in the departure area is subject to thorough control. Passengers themselves, when passing through customs control, are also amenable to inspection by airport security personnel. In case of the slightest suspicion, even if they do not have specific grounds, a suspicious passenger and his belongings are checked with a gas analyzer - a special device that reacts to the slightest trace of any explosives.

In the waiting and departure areas, the airport security personnel are on duty around the clock with service dogs. They patrol the premises and keep order. 
We conducted a survey among 254 tourists from different countries on the subject of security at the airport of Antalya. Respondents gave an affirmative or negative answer to the question: "Do you feel safe at the airport?". By grouping the results, we obtained the following data: $82 \%$ (208 people) of people feel safe at the airport and only 18\% (45 people) do not feel safe. Basically, these tourists had problems with luggage, got lost at the airport, or faced with a language barrier (fig. 4).

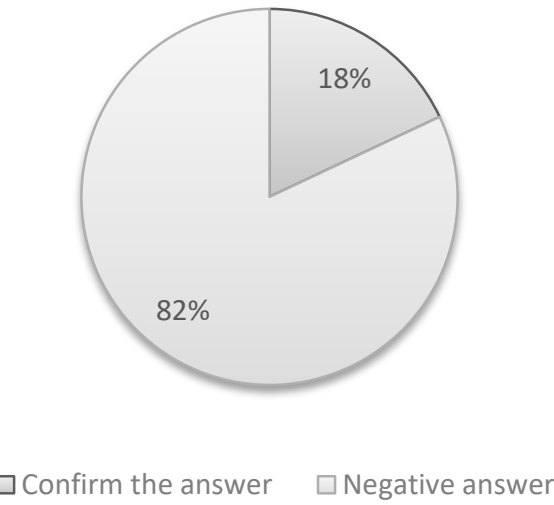

Fig. 4. Results of the survey "Do you feel safe at the airport?" Created on the basis of the obtained primary data

Given these factors, we can conclude that regarding the risk of terrorist threats, Antalya International Airport adheres to enhanced security measures that comply with international standards and enable tourists to feel protected, and the airport itself to hold leading positions in terms of passenger safety among Asian countries.

The transfer is the first thing that awaits tourists upon their arrival at the destination airport. Being the start of the journey it is a calling card and significantly affects the perception of the rest as a whole, even if it does not last long.

Tour operators are trying to make the transfer as comfortable as possible, and most importantly - safe, because Turkey's roads are of very high quality, however, the relief features give rise to special requirements for the driver's professionalism and following of safety instructions.

First of all, tour operators choose modern safe buses and share taxi, which are technically sound, for the organization of transfer. All of them have seat belts on the passenger seats, which are offered to fasten immediately at the beginning of the trip.

On the way to the hotel, a transfer guide is responsible for the safety of tourists. He does not only entertains them, but also provides an introductory safety briefing, as well as monitors over the comfort and safety of passengers.

According to my own observations, the basic rules that should be followed during the excursions are:

1. Do not talk to the locals ( $15 \%$ do not follow the rules).

2. Observe the rules of the tour (33\% do not follow the rules).

3. Follow the guide's instructions ( $25 \%$ do not follow the rules).

Turkey offers its guests a wide range of accommodation facilities at the cost of living, as well as the quality and variety of services. However, the class of the hotel should not affect the safety of tourists.

First of all, it is worth noting the almost total transition of Turkish hotels to a system of electronic locks in the rooms. That is, a tourist receives a card upon settlement, which simultaneously performs the function of a key (when the chip is brought to the reader on the door, the lock opens) and the power switch in the room. Plastic cards are much more reliable than traditional keys and provide guests with confidence in the security of their property during their absence in the room. 
Most hotels have a 24-hour video surveillance system. Particularly pleased that such systems work not only in $4-5^{*}$ hotels, but also in two- and three-star hotels (for example, all floors of the Rios Beach Beldibi hotel, which is considered a $3+^{*}$ class hotel and has a low cost of accommodation, are equipped with surveillance cameras).

With some minor exceptions, things of the guests do not disappear from the rooms. This goes to prove the integrity of the hotel staff, who have access to the rooms even at a time when there are no guests.

The staff at the reception also performs the function of monitoring security, tracking the penetration of people in hotels, preventing the appearance of people in the hotel who do not live there.

Speaking of security, it is worthwhile to dwell in more detail on the information meetings, organized by the tour operator of the receiving party. During the transfer to the hotel, the transfer guide informs tourists about the time of the start of the information meeting in each of the hotels. They often occur on the day of the settlement. Most often the guide conducts information meetings in the lobby of the hotel, explaining security issues to the tourists, and also introducing an assortment of excursions.

Regarding security, they intensively emphasize the rules of this hotel, the list of paid services that are not included in the price (in some hotels, for example, Ambassador Plaza Kemer, drinks in the beach bar are paid, except for drinking water in the cooler). Guides pay special attention to attracting the attention of tourists to the problem of local excursion bureaus, which are very numerous in the hotel zone and which mostly offer trips to attractions and popular excursions to leather and fur factories at significantly lower prices than hotel guides. However, such offices do not bear any responsibility for the safety of tourists, as well as in the case of such voluntary travel, the tour operator disclaims responsibility in case of a dangerous situation.

In general, the vast majority of safety briefings is devoted to contacts with the local population, because there are a lot of examples of the occurrence of an accident risk. This is especially true of women who need to be especially careful in Muslim countries. Also attention is focused to the dangers of numerous trips that the local population organizes in private transport.

Also during the information meetings, the guides provide tourists with phone numbers, Viber and WatsApp contacts, which can be accessed around the clock with questions and problems arising during the holidays.

However, according to our observations, guests often miss the information meetings. I asked the hotel guide to trace 25 meetings and calculate how many guests will visit it. Subsequently, seeing off the guests, he inquired whether there were any problematic situations into which the guests have got. As it turned out, $75 \%$ of tourists who got into a dangerous situation missed the information meetings (fig.5).

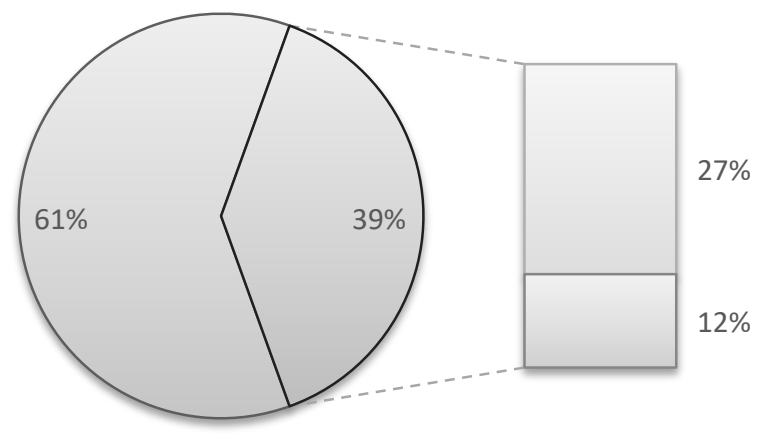

口Visited the inform-meeting

$\square$ Did not attend the informmeeting: Caught in a dangerous situation;

口Did not attend the informmeeting: There are no problems during the rest.

\section{Fig. 5. Results of observing the effects of attendance of information meetings at the hotel} Created by the author on the basis of the obtained primary data

The main importance of information meetings in security matters is that tourists are warned of possible dangers that may be inflicted due to their carelessness and carefree attitude. Information 
meetings delineate the boundaries of the tour operator's responsibility for the life and health of tourists, and provide a list of paid services so that guests mistakenly did not use them. Therefore, visiting such events is in the interests of the tourists. In addition, in each hotel such a meeting will carry a new useful information, so the experience of the tourist does not affect the novelty of the heard information.

Security on the streets of Turkish cities is controlled by patrol police. Dismounted and car patrols maintain public order, especially when holding mass events (recently in Turkey, given the political situation, patriotic youth, who participate in rallies, demonstrations, etc., have intensified, generally creating a fairly safe atmosphere). In addition, the locals in the tourist quarters are affable and friendly to tourists, if the latter show sufficient respect for their culture. The tense situation is perhaps in non-tourist settlements. The tourists are not recommended to go there at all. These quarters are less controlled by the police and the population there may not be as friendly to visitors.

The gendarmerie, which is a subdivision of the Turkish armed forces and operates in rural areas, which is not under the jurisdiction of the city police, also supports public order in the Turkish streets.

Thus, the security on the streets is supported by local governments, which provide patrolling. A significant share of tourism in the income of the local population generates a friendly attitude towards the vacationers. In addition, hospitality is a mental trait of this nation.

According to my own observations, there was a discrepancy between the expected risks during the stay of the tourists on the street and the dangerous situations into which they have got (table 1).

Table 1

Ratio of expected risks and real situations

\begin{tabular}{|l|c|l|c|}
\hline \multicolumn{1}{|c|}{ Expected risks } & $\begin{array}{c}\text { \% of tourists who are } \\
\text { afraid of the event } \\
\text { occurrence }\end{array}$ & Dangerous situations & $\begin{array}{c}\text { \% of tourists who got } \\
\text { into a dangerous } \\
\text { situation }\end{array}$ \\
\hline $\begin{array}{l}\text { To be a victim of a } \\
\text { terrorist attack }\end{array}$ & 100 & $\begin{array}{l}\text { To be deceived by } \\
\text { local people at the time } \\
\text { of purchase }\end{array}$ & 32 \\
\hline $\begin{array}{l}\text { To get sick with a } \\
\text { local disease }\end{array}$ & 87 & Wallet theft & 12 \\
\hline $\begin{array}{l}\text { To get to the local } \\
\text { police station }\end{array}$ & 54 & $\begin{array}{l}\text { To become a member } \\
\text { of a religious conflict }\end{array}$ & 6 \\
\hline
\end{tabular}

Created on the basis of the obtained primary data

Thus, the expected risks are more social in nature. Their absence is ensured mainly at the macrolevel - by police, gendarmerie patrols, special forces of OKK, SAT, SAS.

But the tourists get into the typical situations, which are mainly related to the lack of knowledge of religion and the nature of the locals. Therefore, first of all, it is necessary that every tourist should be scrupulous about the studying of the cultural characteristics of the population before making a trip. He should attentively listen the information, provided by the guides.

Thus, tourism in Turkey, as in any other country, directly depends on the security situation. In addition, being a Muslim country, Turkey is perceived through the prism of stereotypes among the tourists. However, those, who have visited this country, note that they felt safe on the streets of Turkish cities, on the territory of hotels and while traveling around Turkey. This impression is due to the well-organized work of police patrols, a perfect security system in hotels, which value their reputation and an amazingly hospitable mentality of the local population.

The situation with the threat of terrorist attacks is radically different. 2016 has become a difficult year for Turkey in general and for tourism in particular. A series of terrorist attacks and a coup d'état attempt were added to the diplomatic conflict with the Russian Federation, forcing a significant percentage of foreigners to cancel their trips to this country. This decrease in the tourist 
flow provoked significant financial losses for the state, especially given the weight of the share of tourism in the structure of the Turkish economy.

It is worth noting the country's flexible response to this situation: Turkey immediately introduced measures to enhance security (particularly at the airports and crowded places), and also reduced the prices for recreation, attracting more tourists. It helped to quickly return to the same figures after the decline in tourism income in 2016.

It is reasonable to conduct a SWOT-analysis for a clearer and illustrative display of the current state of a tourist's safety policy in Turkey, as well as identifying ways to improve it (table 2).

Table 2

SWOT-analysis of a tourist's safety in Turkey

\begin{tabular}{|c|c|}
\hline $\begin{array}{c}\text { Advantages } \\
\text { (strengths) }\end{array}$ & $\begin{array}{c}\text { Disadvantages } \\
\text { (weaknesses) }\end{array}$ \\
\hline $\begin{array}{ll}\checkmark & \text { high level of security in the airports; } \\
\checkmark & \text { high level of well-developed infrastructure; } \\
\checkmark & \text { state tourism support policy; } \\
\checkmark & \text { holding of informaton meetings in hotels; } \\
\checkmark & \text { development of clear rules for tourists during } \\
& \text { the transfer; } \\
\checkmark & \text { existence of electronic locks system in hotels; } \\
\checkmark & \text { 24-hour video surveillance; } \\
\checkmark & \text { presence of frontline police and gendarmery } \\
& \text { on the streets. }\end{array}$ & $\begin{array}{ll}\checkmark & \text { cultural differences - majority of tourists } \\
\text { are Christians and the Turks are Muslims; } \\
\checkmark & \text { quality of provided services may not } \\
\text { always be high; } \\
\checkmark \quad \text { instability of the national currency } \\
\text { (depreciation by one quarter for the last } \\
\text { year); } \\
\checkmark \quad \text { weak human resources (necessity of } \\
\text { involvement of the foreigners); } \\
\checkmark \quad \text { violation of safe working rules of the } \\
\text { tourism infrastructure employees; } \\
\checkmark \text { climate in some regions is not suitable for } \\
\text { people with cardiovascular diseases; } \\
\checkmark \text { presence of rather dangerous places for } \\
\text { tourists. }\end{array}$ \\
\hline Opportunities & Threats \\
\hline $\begin{array}{l}\quad \text { to increase the number of tourists, who visit } \\
\text { information meetings in hotels; } \\
\checkmark \quad \text { travel agency should inform of behavior at the } \\
\text { airport; } \\
\checkmark \quad \text { travel agency should select a region, taking } \\
\text { into account the health of the tourist; } \\
\checkmark \quad \text { to set measures to prevent tourists from scams } \\
\text { of the local population; } \\
\checkmark \quad \text { to provide tourists with information about a } \\
\checkmark \text { safe holiday; } \\
\text { to develop an application about a safe } \\
\checkmark \text { holiday in smartphones; } \\
\text { to improve working conditions of employees } \\
\text { in the tourism industry. }\end{array}$ & $\begin{array}{l}\checkmark \text { military activities in neighbouring states; } \\
\checkmark \text { earthquakes; } \\
\checkmark \text { acts of terrorism; } \\
\checkmark \text { political instability. }\end{array}$ \\
\hline
\end{tabular}

Created by the author

Thus, we propose to improve a tourist's safety in Turkey through the introduction of some rules at the level of policy of enterprises that belong to different areas of tourism (microlevel policy), the implementation of which needs to be monitored by the local and/or state authorities (meso/macrolevel). We offer to inform tourists at different stages of the tourist product implementation:

I stage: at the level of a travel agency that offers to buy a travel package, the travel agency manager should: 
- inform of behavior at the airport, about what situations may arise, prepare the tourist for them;

- travel agency should select a region, taking into account the health of the tourist;

- inform about the application of a safe holiday in Turkey;

- provide tourists with information about a safe holiday in Turkey: climate, religion, local people, dangerous regions and others.

- II stage: at the level of the host tour operator that provides transfer:

- improve working conditions of employees in the tourism industry (so that employees can perform their duties at high quality standards: be attentive and friendly);

- inform tourists about the dangers, paying attention to whether they remember the information;

- set measures to prevent tourists from scams of the local population.

- III stage: at the level of the host hotel:

- increase the number of tourists, who visit information meetings in hotels;

- improve the quality of information meetings: to make them shorter, more concise, more interesting.

Such complex measures will help to avoid many dangerous situations in which the tourist gets for the internal reasons. It is worth noting that the level of security of the tourism infrastructure of Turkey minimizes the external causes for the occurrence of dangerous situations (strengths of the SWOT-analysis of the tourist safety in Turkey).

Despite a generally well-organized security system, the development of strategic objectives would have a significant positive impact on the development of tourism. In addition, after 5 years, the term of the Strategy for the Development of Tourism in Turkey until 2023 is completed. In view of this, it is worthwhile to suggest the following focal points of a policy:

- coordination of state security bodies and their focus on security in tourist regions;

- keeping tightened security at the achieved level ;

- constant modernization of technical means for their implementation;

- thorough training and retraining of personnel working in the security sector;

- standardization of requirements for means of accommodating crowded places from a security point of view;

- paying significant attention to the safety factor not only in the tourist regions, but also in those, where tourists are less frequent, because the situation in them also forms the image of the country as a whole;

Conclusions. Thus, it can be summarized, that Turkey has introduced effective security measures in response to the recession provoked by the unstable situation. States, in which tourism occupies a significant economic niche, should take care of security, because the losses from a decrease in the tourist flow significantly exceed investments in measures for preventing such situations. First of all, Turkey should respond to the emergence of instability in a flexible pricing policy, as well as carefully monitor security not only in the resort area, but also in the capital and non-tourist cities, because rumors about the occurrence of danger in this region adversely affect the tourist image of the country.

\section{References}

1. Blanke J. (2018). The Travel \& Tourism Competitiveness Reports 2017/ Thea Chiesa; World Economic Forum. - Geneva : [s. n.]. - p. 387.

2. UNWTO Toutism Highlights (2017). 2017 Edition UNWTO. - p. 16.

3. Military coup in Turkey: the chronicle is completed (2018) Retrieved from: http://news.liga.net/news/world/11723398-voennyy_perevorot_v_turtsii_khronika.htm. (in Rus.)

4. I. Panasiuk The key problems and the prospects for the development of Turkish tourism market (2017) Retrieved from: http://www.economy.in.ua/pdf/4_2017/13.pdf. (in Ukr.)

5. Istanbul terror attack (2018). Retrieved from: https://korrespondent.net/world/3785718-terakt-vstambule-podrobnosty-vydeo-foto (in Ukr.)

6. Terror attack in Turkey: officially confirmed: 36 killed and about 150 injured (2016) Retrieved from: http://www.pravda.com.ua/news/2016/06/29/7113105/ (in Ukr.) 
7. Turkey has lost $17 \%$ of revenue from tourism (2017). Retrieved from: https://news.finance.ua/ua/news/1375196/turechchyna-vtratyla-17-dohodiv-vid-turyzmu. (in Ukr.)

8. Turner R. Travel \& Tourism Economic impact 2017 Turkey (2018). London. -24 p.

\section{Глушкова Тетяна Сергї̈вна,}

доцент,

Міжнародний економіко-гуманітарний університет

імені академіка Степана Дем'янчука

Ушакова Оксана Анатоліївна,

фахівець 1-ї категорії, викладач,

Технічний коледж Національного університету

водного господарства та природокористування

\section{СИСТЕМА УПРАВЛІННЯ ЕКОНОМІЧНОЮ БЕЗПЕКОЮ ТУРИСТІВ: ДОСВІД ТУРЕЧЧИНИ}

Проблема. Для багатьох краӥн індустрія туризму є найважливішою статтею й основним джерелом доходів бюджету. Індустрія туризму належить до перших 5 галузей, які приносять найбільший дохід у світі. Відповідно до очікувань Всесвітньої туристичної організації, у найближчі кілька десятиліть сектор туризму стане першим у списку світового експортного обороту. Туризм стимулює розвиток багатьох галузей економіки: промисловості, торгівлі, будівництва, транспорту, сільського господарства, побутового обслуговування, малого та середнього бізнесу, виступаючи каталізатором сочіально-економічного розвитку краӥни. Тому важливим є питання розробки ефективної системи управління економічною безпекою туристів, адже галузь туризму стає основою розвитку країн і регіонів.

Метою дослідження є обтрунтування шляхів удосконалення системи управління економічною безпекою туристів у краӥнах, де туризм є пріоритетним напрямом економічного зростання.

Результати. У статті описано вплив системи управління економічною безпекою туристів на темпи зростання ВВП. Визначено тендениії зменшення туристичних потоків під час актуалізації терористичних загроз. На основі зібраних первинних даних проаналізовано ситуацію з безпекою на вулииях міст Туреччини та територіях готелів, під час трансферу та в аеропортах. Виявлені сильні та слабкі сторони системи економічної безпеки в Турецькій Республіиі, а також загрози розвитку та можливості покращення іï. Враховуючи пряму залежність фінансових надходжень до бюджету Туреччини від ситуаиії з безпекою, робиться висновок про важливість иього фактору для країн зі значною часткою туризму в структурі економіки.

Наукова новизна. Заходи щодо вдосконалення системи управління економічною безпекою туристів, на відміну від наявних, базуються на сучасних особливостях державної економічної політики в туристичній сфері та сучасних аспектах ведення приватного підприємництва, розвитку туристичної інфраструктури, ефективного управління ризиками. Висновки зроблені на основі зарубіжних статистичних джерел та первинних даних, отриманих особисто авторами.

Висновки. Туреччина запровадила ефективні заходи безпеки у відповідь на рецесію, викликану нестабільною ситуацією. Держави, в яких туризм займає значну економічну німу, повинні піклуватися про безпеку, оскільки втрати від зниження туристичного потоку значно перевищують інвестиції в заходи для запобігання подібним ситуачіям. Перш за все, Туреччина повинна реагувати на виникнення нестабільності гнучкою ціновою політикою, а також ретельно контролювати безпеку не тільки в курортній зоні, а й у не туристичних містах. Чутки про виникнення чи існування небезпеки для туристів негативно впливають на туристичний імідж країни.

Ключові слова: туризм, індустрія туризму, ВВП, безпека туристів, система управління економічною безпекою туристів. 